\title{
Effective Use of Appreciation Education in Students Management of Higher Vocational College

\author{
Gui-dong ZENG
} \\ Xijing University, Xi'an, Shaanxi, China
}

Keywords: Appreciation Education; Students Management; Higher Vocational College.

\begin{abstract}
Student management in higher vocational colleges is a complex systematic project. At this stage, students in higher vocational colleges in China have low recognition of higher vocational education, poor self-discipline, lack of initiative, and are prone to inferiority. Moreover, the management mode of higher vocational students is old and lacks professional teachers, which can no longer adapt to the development needs of higher vocational schools. Therefore, the implementation of appreciation education in higher vocational colleges is particularly necessary. Appreciation education can enhance students' self-confidence, guide students to establish a correct outlook on life and career, and cultivate students' self-discipline and self-responsibility.
\end{abstract}

\section{The Basic Concept of Appreciation Education}

Appreciation education is life education, the love education and the education full of humanity and vitality. The most essential need in human is the desire to be appreciated, respected, understood and loved. As far as spiritual life is concerned, everyone comes to the world for appreciation. Appreciation education is characterized by paying attention to people's strengths, allowing children to awaken in the mentality of "I am a good boy", allowing students to advance in the mentality of "I am a good student"; while complaining about education focuses on the weaknesses and shortcomings of children, small problems, infinite exaggeration, so that children self-destruction, in the "I am a bad boy" "I am a bad student" thoughts sink. It is important to emphasize that all children need appreciation, which makes them better and better.

Appreciation can drive success. How educators treat students largely determines the direction of students' development. If the educator has a respectful and appreciative attitude towards the student, then the student will also repay this respect and appreciation, and achieve the expectation of the educator with sufficient enthusiasm and full confidence. On the other hand, if the educator complains about the students, it will not only make the students lose the trust of the educators, but also make the students lose their self-confidence.

The goal of appreciation education is to stimulate the potential motivation of students. Appreciation education differs from traditional educational methods in that it recognizes the differences between students and allows students to fail. Appreciation education pays attention to the students' strengths and strengths, and constantly strengthens its advantages, so that the students' flash points are gradually expanded, and the students' self-confidence is greatly stimulated, thus stimulating the students' potential motivation.

\section{The Necessity of Appreciation Education in Students Management of Higher Vocational College}

\subsection{Current students' status of higher vocational college}

Overall, the mainstream of vocational students is good. However, in recent years, the quality of students, ideas and moral consciousness of higher vocational students have changed a lot, and some new problems have arisen. These new changes and new problems have brought difficulties to the management of students in higher vocational college. The quality of students in higher vocational colleges has been declining year by year. Students have low recognition of higher vocational education and the exclusion psychology varies from different degrees. At this stage, in the consciousness of most people, ordinary higher education is the mainstream, and the recognition of 
the higher vocational colleges is relatively low. This has led most students to read the "three books" at a high price, but the number of students of the higher vocational colleges has decreased year by year, the quality of students has been declining, and the educational and teaching effects are not satisfactory. At the same time, students entering higher vocational colleges have lower recognition of higher vocational education. Most of the students in higher vocational colleges are fading after the beautiful vision of an ideal university is gradually shattered. Only after choosing the higher vocational colleges, this passive and helpless choice makes students' trust and recognition of higher vocational education very low, and the lack of understanding of higher vocational education, so it has a rejection psychology, which further increased the difficulty of management. Higher vocational students have strong personality, poor self-discipline, and disobey management. At present, most of the students in higher vocational colleges are the only children of the "post-90s". They have a superior living environment, strong individualistic ideas, self-centered, very strong personality, and disobey the management of the school, mainly characterized by selfishness and indifference, arrogant, without knowing how to care about the collective and others, not easily accepting opinions from others. Higher vocational students are prone to inferiority. Relevant surveys show that the ideals and goals of higher vocational students in the middle and high school are also very good, but because of the failure of the college entrance examination, they failed to enter their ideal university. The huge frustration made them have to return to reality and start to re-examine. I doubt my own ability, and even breed inferiority, specifically manifested as not being able to face up to my identity, escaping from reality, breaking a jar, blaming others. The psychological imbalance and the role of inferiority make it difficult for students to adapt to higher vocational learning and life after entering school. The higher vocational students are too relaxed and lack initiative. After many high-school students entered the campus, they thought that they were finally "suddenly", so they lost the enthusiasm for learning in high school and did not have a positive attitude towards learning and competition. In school life, they do not paying attention to the cultivation of good behavior habits, lacking the moral quality improvement and lack of urgency. The specific manifestation is that they do not abide by school discipline, do not earnestly complete the coursework, do not listen to the teacher's words, and disdain the management of the school and so on.

\subsection{Problems in the students management of higher vocational college}

The students management in higher vocational colleges is a complicated systematic project. The difficulty of higher vocational management is not only difficult for students to manage, but also the management work itself has great problems. First, the management model is old and lacks innovation. At present, higher vocational colleges adopt a traditional model for student management. This traditional model has played a positive role in correcting students' bad behavior habits and ideology in a certain historical period, but this management regards students as management objects, does not grasp the students' needs for individuality and respect, and lacks communication with students in management methods, which is likely to cause students' resistance or even rebellious psychology. Students who are cultivated under such a management model lack the ability to think independently, lack innovation and have strong dependence. This lack of scientific, proactive and innovative management model has been out of touch with the development of the times and cannot meet the higher-level needs of students. Second, there is a lack of professional teachers to undertake the ideological and political education. At present, the core of student management in higher vocational colleges is the counselor, giving full play to the role of counselors and managing the class well is the key to fully mobilize students' enthusiasm and initiative, and realize the all-round development of students' morality, intelligence and beauty. However, in reality, the counselor does not undertake the task of teaching, has limited knowledge of the professional learning of the students, and the counselor manages a lot of affairs, it is difficult to achieve the desired management effect. Therefore, the close cooperation between professional teachers and student management work and full-time counselors is undoubtedly complementary. 


\section{The Application of Appreciation Education in the Students Management of Higher Vocational College}

\subsection{The role of appreciation education in the students management of higher vocational college}

Appreciation education is both a new teaching concept and an effective teaching method. Studies have shown that the role of appreciation education in the management of higher vocational students is very obvious, for example, to redefine the criteria for student evaluation and enhance students' self-confidence. Today, in a highly competitive social environment, higher vocational students face more external pressures. Without proper guidance, the pressures on students can not be solved, and they cannot be transformed into internal motivation. This will make higher vocational students lose confidence. Lose the motivation to learn. The loss of self-confidence makes students relax their self-request, self-control ability, and lack of correct life goals. In fact, higher vocational students are not without life goals, but their life goals are not recognized. In higher vocational education, they cannot find opportunities to achieve their goals in life. Therefore, the application of appreciation education in the management of higher vocational students, from respecting and affirming the goals of students and the ways to achieve them, can make students establish self-confidence. Appreciation education allows the existence of gaps. The evaluation of students is based on the flash point of students, so that students can be motivated to a greater extent, so that they can stimulate their internal motivation and achieve their goals with full confidence. Therefore, the key to implementing appreciation education is that teachers should be good at discovering the bright spots of students, change the original evaluation concept based on achievement, let students know themselves, affirm themselves and face themselves.

Advantages, then expand the students' advantages, and encourage students to carry forward the advantages to achieve the goal. Appreciation education can guide students to establish a correct and positive world view and career outlook. At present, high vocational students are generally unclear about higher vocational education, and they are not sure about their own positioning. Appreciation education can help students get out of the misunderstanding of higher vocational education by continuously strengthening vocational education for students. In the classroom teaching, students can be told about the broad prospects of the professional curriculum, so that students are full of confidence in the future and have a stronger interest in learning. By appreciating education to cultivate students' self-confidence, they can also correct students' bad habits and encourage students to form a correct understanding of the school and even the society and form a positive world view.

Appreciation education can cultivate students' self-discipline and enhance students' self-control ability. University life is an important turning point in life, requiring students to develop independently. But most students don't have enough mental preparation for college life.

The current transition between high school and university often leads to a sense of disorientation. Higher vocational students are more likely to fall into a slack and loose state. In response to this situation, when implementing the appreciation education, we must carefully listen to the true feelings of the students, understand and understand them in depth, and be good at discovering the merits of each student and appreciating the individuality of the students. While understanding and appreciating, we must educate students to strengthen self-discipline and encourage students to believe in self, challenge themselves, enhance self-control, and cultivate students' good habits of being self-disciplined. The way to appreciate education is diverse, it can be a language of praise, or it can be an eye for encouragement. In the implementation of appreciation education, higher vocational colleges should pay attention to the whole, pay attention to each student, especially the students with obvious defects, and more need the educators to pay respect and care from the heart. Through appreciation, students' self-esteem can be greatly stimulated, and students will be encouraged to grow up in the "good student" mentality, more consciously comply with the constraints of school rules, and move in the right direction of development. Self-esteem is a prerequisite for self-discipline. The student's self-esteem is satisfied, and he will consciously and actively restrain himself.

My own bad behavior, pay more attention to my words and deeds, self-control ability is 
unconsciously enhanced.

Appreciation education can cultivate students' sense of self-responsibility. Appreciation education praises and encourages students through understanding, tolerance, and respect, trust, and encouragement. However, we must pay attention to the degree when implementing the appreciation education. Haim G. Ginott pointed out in his book Between Parent and Child that "praise, like penicillin, must not be used at will. There are certain criteria for the use of potent drugs that require caution, including time and dosage, because they can cause allergic reactions." This requires us to abide by the correct evaluation principles and to appreciate them. Appreciation is not a principle less praise, but it is not a cure for all diseases. In the implementation of appreciation education, teachers should avoid unrealistic praise, in the process of interaction with students, we must pay attention to avoid appreciating the surface, which will leave a "false" impression on students. Unexpected appreciation can lead to the vanity of students, leading to the formation of bad habits such as falsification. Appreciation of education advocates more positive and praise for students, but it does not mean that students do not criticize if they are wrong. If the teacher still recognizes the student's mistake, it will encourage the student to escape the responsibility and gradually make the student lose responsibility. Therefore, when appreciating education, it is necessary to appreciate the degree, the mistakes of the students, the teachers should find out the solution in time, give correct guidance, and avoid the students making the same mistake again. When pointing out the students' mistakes, we should pay attention to the use of appropriate skills, which will not harm the students' self-esteem, but also mobilize the enthusiasm of the students to change, and then form the courage to take responsibility and enhance self-responsibility.

\subsection{Specific application measures for appreciation education}

Cultivate teachers' awareness of appreciation and improve the overall quality of teachers. In appreciation education, teachers play an important role. Teachers should be good at discovering the flash points of students and then appreciate them to guide students in the right direction. This requires teachers to first correct the previous criticism-based teaching concepts, cultivate awareness, and quickly explore the flash points of students, and then expand them. At the same time, appreciation education has high requirements for the overall quality of teachers. It is not enough for teachers to appreciate students only, but also for students to recognize this appreciation. Students recognize the appreciation of teachers and require teachers not only to have a strong teaching ability, but also to have trustworthy character and ability to guide. Therefore, to promote appreciation education in the management of higher vocational students, it is necessary to change the concept of teachers, cultivate teachers' awareness of appreciation, and improve the overall quality of teachers. Teachers need to understand every student. The teacher explores the flash points of the students and builds on the teacher's understanding of the students. Teachers' understanding of students is not only to understand each individual's learning situation, but also to fully understand each student's interests, hobbies, specialties, and family. Only by knowing the situation of each student can the teacher make a different appreciation evaluation. Teachers should pay close attention to the psychological changes of students. Teachers should pay close attention to the psychological situation of students. In addition to constantly enhancing students' self-confidence and cultivating students' positive outlook on life through appreciation, they should also be aware of the psychological changes of students. For example, for the same learning content, students have different reactions, and some may be discouraged because of poor foundation. Under such circumstances, teachers should individually encourage students and adjust the teaching content and methods appropriately. Teachers should care about student life. The daily life of students is an important part of student management, and teachers should care about the life of students. The communication between teachers and students is limited to the distance and distance between the classrooms. In order to strengthen the understanding of the students, the teachers can care about the students' lives and provide solutions and necessary assistance for the problems encountered in the students' lives. 


\section{References}

[1] Chao Ye. Appreciation Education and Extrusion: A Discussion on Student Management Methods in Private Vocational Colleges [J]. China Vocational and Technical Education, 2015 (35).

[2] Yuli Huang. Application of Appreciation Education in Class Construction of Higher Vocational Colleges [J]. Contemporary Youth Education, 2016 (2).

[3] Tie Song. "Appreciation" Education and Students' Self-management — On the Management of Students in Higher Vocational Colleges [J]. Examination Weekly, 2015 (32).

[4] Hong Zhou. Awakening Appreciation Education Lecture Essentials Reader [M]. Beijing: Beijing Publishing House, 2017 (15).

[5] Huanqin Deng. On the Appreciation Education in the Management of College Students in Higher Vocational Colleges [J]. China Electric Power Education, 2009 (6). 